\title{
Spinal cord injury patient treated with cell-based therapy and CellSonic VIPP
}

\author{
Andrew Hague* \\ Professor of Advanced Medicine, President, Cellsonic, Manufacturers of Medical Equipment, UK
}

\section{Case Study}

The patient had a road traffic accident and sustained injuries in his spine in September 2017. He was paralyzed below the waist and was bedridden since the accident. He did not undergo any major treatment at his home country. He was brought to our hospital on a stretcher. With cell-based therapy and CellSonic VIPP plus neurorehabilitation, the patient was able to stand with the help of callipers within a month of treatment. This is tremendous improvement as the family was told that the boy will remain bedridden. He had developed bed sores due to lack of movement. With the combination treatment of cell-based therapy and CellSonic VIPP in the wound area, we could accomplish rapid healing of the sores. Overall the improvement is very encouraging.

After few months of follow up, we will look to publish this case. We have few more cases in the pipeline and we hope to publish them in reputed journals after the required follow up period.

https://www.youtube.com/watch?v=kK3YY7Zk1ZQ\&t=110s
Copyright: ( $\mathrm{C} 2018$ Hague A. This is an open-access article distributed under the terms of the Creative Commons Attribution License, which permits unrestricted use, distribution, and reproduction in any medium, provided the original author and source are credited.
${ }^{*}$ Correspondence to: Andrew Hague, Professor of Advanced Medicine, President, Cellsonic, Manufacturers of Medical Equipment, UK, Tel: +1 315210 6307; E-mail: cellsonic.beauty@gmail.com

Received: May 07, 2018; Accepted: May 19, 2018; Published: May 22, 2018 